\title{
Examining the Gap in the Earned Income Tax Credit
}

\author{
by Jennifer Lewis
}

O ne of the largest federal anti-poverty programs, the Earned Income Tax Credit (EITC), is implemented through the tax code and helps lift millions of workers above the poverty threshold. The EITC provides workers with increased financial flexibility and in many cases incentivizes saving among those who would not otherwise be able to set money aside. However, a large disparity exists in the size of the credit for workers with and without dependents, as workers with children receive more than six times the amount a childless worker receives. Because of the benefits associated with the EITC, including its poverty-reduction capabilities and labor supply incentives, many policymakers are calling for an expansion of the program to mitigate this gap. In addition to analyzing the EITC in its current form and several proposed expansions, this article also examines an evaluation of a pilot expansion program occurring in New York and Atlanta. 


\section{BACKGROUND}

Critical spending and entitlement programs rely on tax revenue to continue their work. However, many Americans may not be aware of the powerful role the tax code plays in directly reducing poverty. The Earned Income Tax Credit (EITC) is one of the most important tax expenditures for low income workers, as it can act as a wage supplement to counteract the payroll tax burden (LaLumia 2013). For many families, it is the largest payment they receive throughout the year (GoodmanBacon and McGranahan 2008). It is a refundable credit distributed to eligible workers who file an IRS 1040 Individual Income Tax Return form, and the credit can be disbursed directly into the worker's paycheck or in a lump sum payment. Workers can receive the benefit even if they do not owe any tax liability, which is the case for the majority of EITC-eligible workers (Trampe 2007). Many workers choose to receive the credit in a lump sum payment, which is usually disbursed in February or March (LaLumia 2013; Goodman-Bacon and McGranahan 2008). Families can use the money they receive from this credit in a variety of ways, and many choose to pay down debt, purchase necessities, or make long-term purchases such as vehicles that they would be unable to make without the credit (Linnenbrink et al 2006; GoodmanBacon and McGranahan 2008).

While the EITC is a crucial povertyreducing program, it leaves an important group of taxpayers behind: childless workers. The EITC is popular with lawmakers on both sides of the aisle, and some have called for its expansion to address childless workers, which it puts at a comparative disadvantage to working parents (Marr et al 2014; Carasso
2008; Paletta 2014). Part of the American Recovery and Reinvestment Act of 2009 (ARRA) increased benefits for workers with three or more children and those filing joint returns. However, these ARRA expansions did not affect childless workers (Meyer 2010). The success of the current policy in reducing poverty indicates that an increased credit for childless workers could lead to positive outcomes, such as enhanced labor supply and greater benefits for children of noncustodial parents. Because many states have their own version of the EITC, evaluations of expanded programs implemented at the state and local level could be used to inform federal policy (Miller et al. 2015).

\section{EITC BY THE NUMBERS}

The EITC is instrumental in reducing poverty and supplementing the wages of those in need. In fiscal year 2015, approximately 27 million taxpayers received more than $\$ 66$ billion in EITC credits (IRS 2016). The credit lifted 1.4 million Americans above the poverty line, making it one of the largest anti-poverty programs in the country (Executive Office of the President 2014; Eissa and Hoynes 2006). However, the level of assistance varies depending on several factors, including age, wages, and number of dependents. For childless workers, the credit is limited to those between the ages of 25 and 64, and it is phased in at a rate of 7.65 percent (Marr et al. 2014). Therefore, as income increases, the amount of the credit increases by income multiplied by the phase-in rate, until it reaches the "plateau" income threshold, which is the minimum income amount for the maximum credit benefit (Goodman- 
Bacon and McGranahan 2008). The phaseout rate has similar logic, and is also 7.65 percent (Urban Institute and Brookings Institution Tax Policy Center 2016).

As illustrated in Figure 1, the 2016 phase-out rate for childless workers started at $\$ 8,270$, with a maximum income limit of $\$ 14,880$. The childless worker maximum credit amount of $\$ 506$ is in stark contrast to the maximum credit of a worker with just one child: $\$ 3,373$. Workers with three children receive a maximum benefit of $\$ 6,269$, and when they reach the upper income threshold of $\$ 47,955$, the credit is completely phased out (Urban Institute and Brookings Institution Tax Policy Center 2016).

Some disparity in the maximum credit amount available to workers with and without children is natural, given the additional resource constraints families with children face and the need to target funding towards children's well-being. However, proponents of expansion for childless workers argue that this disparity is too large.

The EITC provides a small amount of assistance for childless workers, which does little to offset the burden imposed by income and payroll taxes. In 2012, 1.2 million childless workers dropped below the poverty line and another 5.8 million fell deeper into poverty due to their federal income and payroll tax liabilities (Marr and Huang 2015). The credit begins to phase out as incomes grow beyond $\$ 8,270$, which is just 66 percent of the federal poverty line for a single, childless adult under the age of 65 (United States Census Bureau 2017). The disparity between the assistance received by workers with children and those without is dramatic: "[T]he average

Figure 1. EITC Parameters 2016

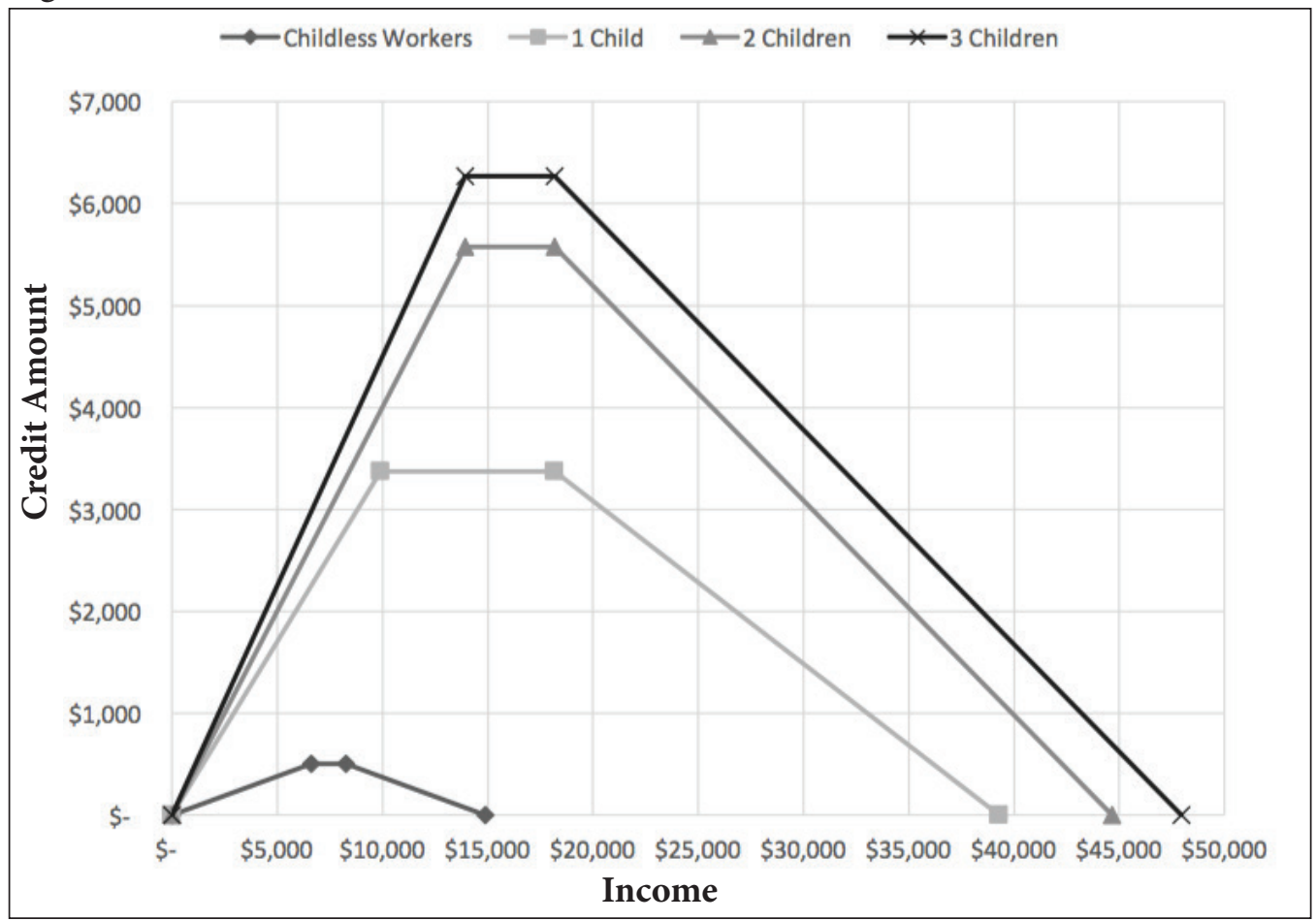

Source: The Urban Institute and Brookings Institution Tax Policy Center 2016 
credit for eligible workers between ages 25 and 64 is only about $\$ 270$, or less than onetenth the average $\$ 2,970$ credit for tax filers with children" (Marr and Huang 2015). A single full-time worker with two children and an $\$ 8$ hourly wage would have received about $\$ 5,460$ from the EITC (Miller et al. 2015).

Figure 2 displays the percentage of poverty reduction attributed to the EITC

Figure 2. Percentage of Poverty Reduction from the EITC in 2012
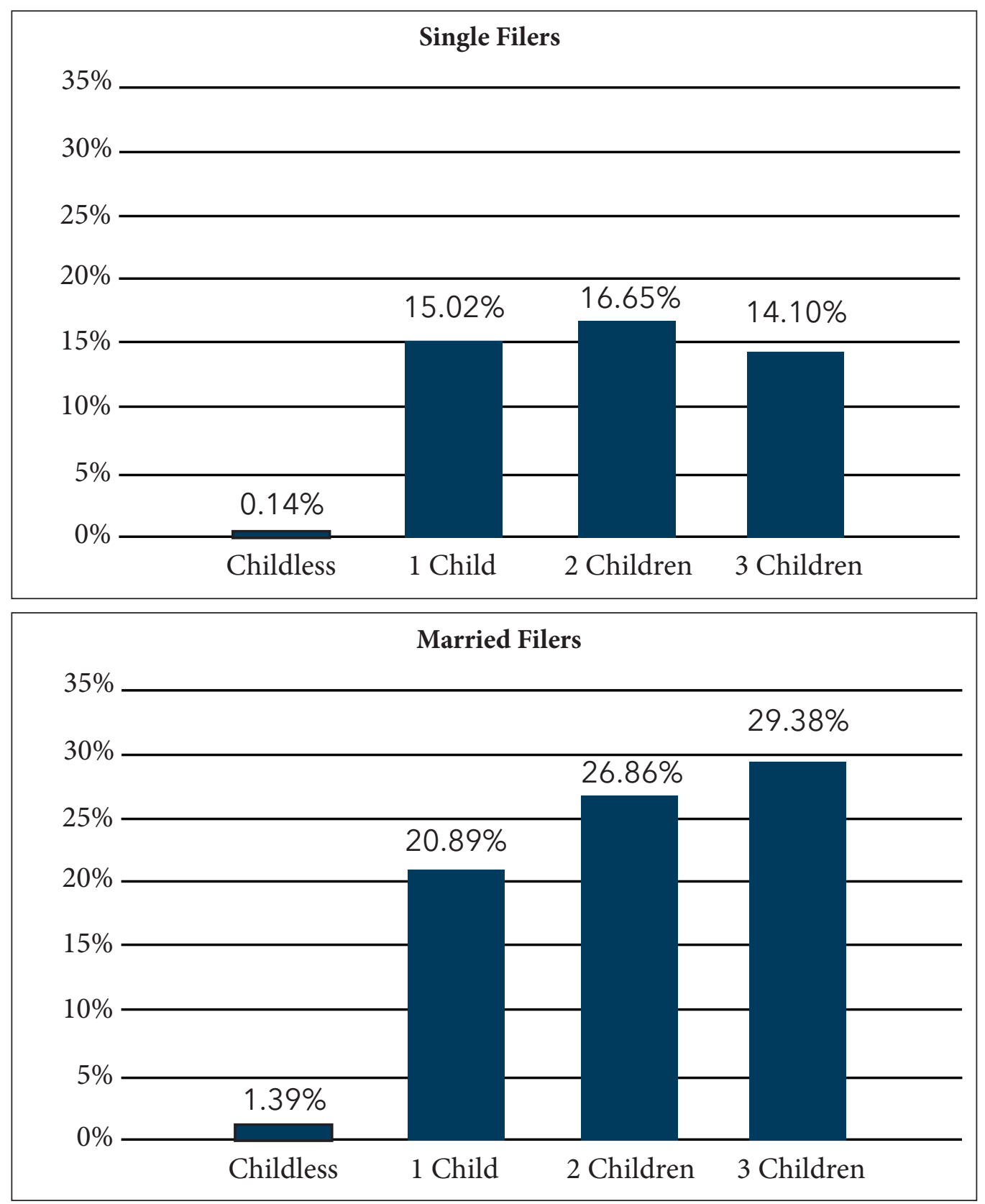

Source: Crandall-Hollick 2015. Congressional Research Service analysis of the 2013 Current Population Survey 
for single and married childless workers. While the reduction ranges from 14 to 29 percent for single versus married workers with three children, the reduction for childless workers remains at approximately one percent (Marr et al. 2014). Therefore, the EITC has a clear and significant gap in the assistance it provides to childless workers.

In addition to providing a much smaller credit for childless workers, those under the age of 25 are excluded completely (Executive Office of the President 2014). This eligibility range was likely intended to prevent aid for young workers still receiving financial support from their parents. However, the minimum age could exclude low-income workers who do not have other sources of financial support, and the employment rates of childless workers in this age range with lower levels of education have been declining. Marr and Huang explain, "Between 1989 and 2013, the employment rate of childless men aged 20 to 24 with a high school education or less fell from 89 percent to 70 percent. The employment rates for the women in this group also fell sharply, from 84 percent to 66 percent" $(2015,5)$. Extending EITC benefits to young workers could slow the declining employment rates by increasing the labor supply incentive. In addition, workers above age 64 are excluded, as legislation has not been updated to reflect the increase in the age at which workers can begin claiming Social Security benefits (Executive Office of the President 2014).

\section{BENEFITS OF THE CREDIT}

When considering an EITC expansion for childless workers, it is important to first establish what benefits, if any, the credit provides in its current form. In addition to reducing the number of workers below the poverty line, the EITC has positive subsidiary outcomes. The benefits explored in the following section include behavioral responses to the phase-in region of the credit, marriage benefits, crime reduction, and positive impacts on children's health and wellness.

One benefit of the EITC structure is an increased labor supply incentive. Economic theory suggests that entering the phase-in region of the EITC should increase labor supply among single parents and primary earners, as there is a greater monetary reward to entering the labor force (the extensive margin) and increasing the numbers of hours worked (the intensive margin). Empirically, there is more evidence for this theory along the extensive margin, as the EITC provides an incentive for unemployed workers to enter the labor force (Maag 2015; Eissa and Hoynes 2006). Research has indicated positive changes in employment among single mothers with two or more children (who are eligible for a larger phase-in rate) in comparison to demographically similar women with one child, particularly among those with lower levels of education (Adireksombat 2010; Hotz et al. 2006). Similarly, studies have shown larger increases in labor force participation rates for single mothers with more children who receive a larger EITC benefit, indicating a positive association between the credit and employment (Evans 2014; Edelman et al 2009).

While there has been little research on the labor supply effects of the EITC for childless workers, EITC expansion in the 1990s for families with children was associated with higher employment rates for eligible low-income single mothers than similar non-eligible women 
(Marr and Huang 2015). Expanding the credit to childless workers could create similar extensive margin increases in labor participation (Edelman et al 2009; Executive Office of the President 2014). However, unlike the evidence for the motivation to enter the labor force, the incentive to work more hours (the intensive margin) is less clear (Evans 2014; Eissa and Hoynes 2006).

Another benefit of the EITC is the behavioral response to entering the phase-in region of the credit, which could encourage employment and mitigate the payroll tax's distortion of labor supply. The "substitution effect" of the payroll tax disincentivizes work by reducing takehome pay (Slemrod and Bakija 2008, 122). Workers might choose to reduce their labor supply or drop out of the labor force completely because payroll taxes diminish their immediate earnings, making leisure time a more appealing substitute for work. Therefore, by increasing the benefit received for additional earnings within the credit phase-in region and plateau, the EITC could reduce the substitution effect of the payroll tax. Single mothers are eligible for a larger credit than childless women and constitute nearly threequarters of EITC recipients. Within this demographic group, there is evidence in support of a labor supply incentive effect within the phase-in region, as the amount of the benefit grows as earnings increase (Eissa and Hoynes 2006).

Unfortunately, a behavioral response to the credit is unlikely if the credit amount is too small to motivate workers (Edelman et al. 2009). In 2013, a single childless worker with wages at the poverty line $(\$ 12,119)$ would owe $\$ 1,139$ in payroll taxes and income taxes while receiving an
EITC of just \$139, which would do little to offset this payroll tax burden (Marr et al. 2014). In 2015, if this worker earned the federal hourly wage of $\$ 7.25$ while working full-time, he or she would receive a credit of only $\$ 25$, a benefit too small to have an impact on whether he or she decided to work or not (Maag 2015). Increasing the childless EITC credit could incentivize unemployed workers to enter the labor force and encourage employed workers to increase their participation.

The expansion of the EITC could also provide marriage benefits for childless workers. People who experience the financial rewards of labor force participation in the form of wages and EITC benefits may be more attractive as potential marriage partners. Marriage has additional poverty reduction benefits, such as sharing the burden of household expenses and duties, and married males in particular are less likely to engage in criminal and drug-related activities (Marr and Huang 2015). However, due to the nature of most federal benefits, wherein married couples usually file jointly and the benefit varies by income, some experience a marriage penalty. Because joint income is subject to the same rate structure as single income, a married couple could enter the EITC phase-out threshold more quickly than they would as single filers. They could also be excluded completely when they combine their incomes (Carasso et al 2008; Maag 2015). Adjustments to the EITC credit for childless workers could address the marriage penalty associated with joint filers. Proposed adjustments include extending the plateau region of the credit, lowering the phase-out rate, and creating a "second-earner deduction," which would reduce taxable income for 
joint filers. An expensive possibility would be doubling the credit for married couples in comparison to single filers (Meyer 2010). Addressing the marriage penalty associated with filing jointly would bolster the demonstrated social and economic benefits that accompany marriage.

Finally, expanding the EITC for childless workers could also positively impact children. Childless workers could become parents in the future, and a larger credit would augment their financial stability prior to parenthood, benefiting their future children (Marr and Huang 2015; Edelman et al. 2009). Expansion could also affect workers whose children who do not meet the EITC qualifying child regulations. Approximately 1.5 million or more "childless" workers are non-custodial parents, so any benefits they receive and contribute to child-rearing expenditures could improve their child's well-being (Executive Office of the President 2014). While custodial parents working full time at the minimum wage and receiving full child support are likely to be lifted above the poverty line by the EITC credit, equivalent non-custodial parents are likely to be pushed below the poverty line (Sorensen and Wheaton 2010). Therefore, expanding the credit to non-custodial parents would increase their ability to contribute to childrelated expenditures such as child support, benefiting their children (Edelman et al. 2009).

\section{SUPPORT FOR EXPANSION}

While the credit understandably targets workers with children as its primary beneficiaries due to the budget constraints of federal discretionary spending, policymakers on both sides of the aisle indicate that expanding the credit for childless workers would provide additional benefits. For example, politicians such as former President Barack Obama and Speaker of the House Paul Ryan (R-WI) advocate continuing to distribute the credit as a tax expenditure and expanding its scope for childless workers. It could be more politically palatable than other government spending programs for low income Americans because it rewards employed earners (Marr et al. 2014). Obama first announced his support for increasing the childless worker EITC in his 2014 State of the Union address (Paletta 2014). He subsequently included a section on EITC reform in his fiscal year 2016 budget. Ryan also expressed his support for expansion and introduced a very similar proposal in 2014 (Marr and Huang 2015).

These proposals would address several components of the program that currently limit the credit for childless workers. First, Obama and Ryan's proposals would expand the eligibility age range to include workers 21 to 67 years old (Marr and Huang 2015). This expansion would particularly impact young workers who do not receive support from their parents and yet are excluded from receiving benefits, creating labor supply incentives and providing some assistance. This age range also captures workers left behind by the increase in the Social Security eligibility threshold (Executive Office of the President 2014).

More importantly, Obama and Ryan's proposals would offset the burden of federal taxes on these low-income childless workers. Payroll taxes equal 15.3 percent of a childless worker's income (including the employer's share). Therefore, the proposals would raise the credit's phase-in rate from 7.65 percent to 15.3 percent. In addition, the credit would phase out entirely at 
$\$ 18,050-125$ percent of full-time earnings at minimum wage and more than $\$ 4,000$ above the existing income ceiling for childless workers (Marr and Huang 2015). These proposals were projected to have significant poverty-reduction capabilities through increasing the maximum amount of the credit. Specifically, "under the Obama and Ryan proposals the credit for a childless adult with wages at the poverty line (projected at $\$ 12,566$ in 2015) would jump from $\$ 172$ to $\$ 841$ in $2015 "$ (10). According to Treasury estimates, these proposals would lift more than half a million workers above the poverty line and reduce the poverty level of 10 million more (Marr et al. 2014). Similar proposals from Representative Richard Neal (D-MA) and Senators Sherrod Brown (D-OH) and Dick Durbin (D-IL) would increase the credit from approximately $\$ 1,000$ in the Obama proposal to $\$ 1,400$. As with Obama and Ryan's proposals, the phase-in and phase-out rates would be increased to 15.3 percent to completely offset the payroll tax burden of childless workers (Kneebone and Williams 2014).

\section{OPPOSITION TO EXPANSION}

Although the dialogue surrounding expanding the EITC for childless workers is generally positive, there are some areas of opposition. The timing of the disbursement and the possibility of more effective policy alternatives, such as minimum wage increases, have been cited as issues with the current program. In addition, the high volume of payment errors, limited scope of the IRS administrative capabilities, and possible labor supply disincentives or wage suppression have also been listed as problems. Critics also indicate that the overall costliness of the existing EITC program should preclude an expansion for childless workers.

One critique centers on the timing of credit disbursement, which most workers choose to receive in an annual lump sum. Detractors question whether a monthly wage supplement would be preferable to an annual refund, as it would allow recipients to smooth their consumption over time. Senator Marco Rubio (R-FL) introduced his plan for reforming the EITC in an address delivered on the 60th anniversary of the War on Poverty in 2014. In this address, he proposed a monthly wage supplement to replace the EITC (Rubio 2014). This supplement would be the same size $(\$ 2,000)$ for every worker, regardless of their number of dependents. To offset the loss workers with children would experience under this reform, he suggested an increase in the Child Tax Credit to $\$ 2,500$ (Schuyler and McBride 2014).

Rubio's suggestion to increase the Child Tax Credit is not the only policy alternative that has been proposed. Minimum wage increases have also been suggested as a substitute for the EITC. However, the EITC more effectively targets benefits toward low-income workers than would an increase in the minimum wage. For example, children and secondary earners in higher-income families would not qualify for EITC benefits, but they would benefit from a minimum wage increase (Meyer 2010). A minimum wage alternative would be an inadequate replacement for the EITC.

Another important area of criticism is the large volume of errors in payment. The EITC has a higher frequency of improper payments and abuse than other tax expenditures. The improper payment 
rate for fiscal year 2015 was estimated to be 23.8 percent (between 21.6 and 25.9 percent) of all program payments; these errors totaled roughly $\$ 15.6$ billion. High program turnover, return preparer errors, and fraud contribute to these overpayments (Payment Accuracy 2016). The largest error among return filers is associated with qualifying-children residency regulations, which stipulate that the child must reside more than half of the year with the parent (Payment Accuracy 2016; IRS 2008; McCubbin 2000). Unlike wage data, the IRS does not have access to administrative data about where a child resides throughout the year, making it difficult to verify claims of dependents (Maag 2015). The complexity of the EITC stipulations exacerbate this problem (McCubbin 2000).

While an expansion of the credit for childless workers would avoid the concern about qualifying-children regulations, the volume of payment errors is a significant issue with the EITC. In addition, the IRS has limited resources available to administer and monitor the credit, contributing to the payment errors. For example, other benefits are typically distributed with a caseworker model. The caseworker model reduces error, but it increases the administrative costs. In contrast, the EITC administrative costs are only one percent of the benefits disbursed (Payment Accuracy 2016). These low administrative costs indicate that the IRS has a limited capacity to undertake errorreduction measures or root out potentially fraudulent claims. As an example of the complexity of the EITC stipulations, the EITC guidebook for individuals is over 37 pages long, which leads many to engage paid preparers when they file for the credit (Edwards and de Rugy 2015). Over 40 percent of EITC refunds are filed by a paid preparer, and nearly half of these returns included an overclaim (Holt 2016).

In addition to the possible monthly wage-supplement alternative and high error rate concerns, detractors also point to the credit plateau and phase-out regions as a labor supply disincentive, converse to the incentive effect of the phase-in region of the distribution. Theoretically, the plateau and phase-out regions should discourage working more hours, as the reward decreases as income increases (Edwards and de Rugy 2015). This hypothesized work disincentive would exist for all those who are already employed, except for single parents who have the lowest wages, as they do not reach the plateau income level (Eissa and Hoynes 2006). One study did find a small but statistically significant labor disincentive effect in the phaseout range (Trampe 2007). However, the majority of the empirical evidence does not support this theoretical decrease in number of hours worked in the plateau and phase-out regions (Edwards and de Rugy 2015; Eissa and Hoynes 2006). The behavioral unresponsiveness regarding the number of hours worked is likely due to the inability of most workers to manipulate their work schedule on a continuous scale, the effect size being too small to estimate, and workers' lack of awareness of the EITC stipulations for the plateau and phase-out regions (Eissa and Hoynes 2006; Meyer 2010).

Critics also cite possible wage suppression as a problem with the EITC in its current form and as an argument against its expansion. Using a supply and demand curve, as labor supply increases, the supply curve shifts to the right and wages decrease to reach the new equilibrium point. 
Therefore, the more workers there are in the market, the less each would theoretically be paid. This potential wage suppression would negatively impact childless workers in particular, as their EITC benefits are not large enough to counteract the theoretical decrease in earnings (Edwards and de Rugy 2015).

In addition to the existing cost of the program, which has risen over the years, detractors point out that the proposed expansions for childless workers would be expensive. Because it is a refundable tax credit, workers with no income tax liability are eligible to receive benefits, making the EITC predominantly a spending program. Indeed, in $2015 \$ 60$ billion -88 percent of the total benefits - were disbursed to filers who had no tax liability (Edwards and de Rugy 2015). The current cost is already significant, and expansion would increase it even more. Obama's proposal would invest an additional $\$ 6.5$ billion into the program, which would still be $\$ 2$ billion less than the Neal/Brown-Durbin proposal totaling $\$ 8.8$ billion (Kneebone and Williams 2014). While these criticisms are valid, benefits such as poverty reduction, increased labor supply incentives, and enhanced social well-being make a powerful case for EITC expansion.

\section{EXPANSION IN PRACTICE}

Two cities have launched experimental programs expanding the EITC, which could provide foundational knowledge for a potential federal EITC change. New York City and Atlanta are piloting implementations in 2015-2017 that provide expanded credits for single adult workers without dependent children, which could offer insight into the possible outcomes for a national policy change. The New York
Paycheck Plus program is funded by the city's Center for Economic Opportunity and the U.S. Department of Health and Human Services. New York City's Human Resources Administration (HRA) is spearheading the implementation using a rigorous design and methodology, which will then be evaluated by the nonprofit research organization MDRC.

The "Paycheck Plus" program increased the maximum benefits from approximately $\$ 500$ to $\$ 2,000$ for childless workers. In addition, the program doubled the eligibility range to include incomes up to $\$ 30,000$. The HRA recruited 6,000 participants in 2013-2014 and randomly assigned them to either the treatment group, which received the larger benefit, or the control group, which received existing tax credits. Additional data collection includes multiple sources, such as administrative records and survey research. While little preliminary data is available so far, the program boasts a "take up rate," or percentage of eligible adults who receive the credit, of about 71 percent. This is higher than the national average for adults without children, which is about 56 percent (Miller et al 2015). The evaluators found this preliminary measure of the program's take up rate to be encouraging, as it was both within their expected range and higher than the national average.

The United Way of Greater Atlanta has partnered with the evaluating organization MDRC to replicate New York City's Paycheck Plus program in Atlanta. Atlanta workers have lower wages on average than New York workers and a greater concentration of labor in the production and transportation sectors (Miller et al. 2015). If the program shows promising labor supply outcomes in two cities with 
regional variation and different labor force composition, it could indicate that the positive outcomes would prevail at the federal level. Introducing the program in two distinctive cities enhances the scope of the research and provides greater external validity to the design, increasing its potential generalizability to other cities across the United States. Using administrative and participant survey data, evaluators will analyze the primary outcome measures in the study: labor force participation, earnings, marriage, criminal activity, child support payments, and financial hardship. Because the program concludes in 2017, not enough data has been gathered yet to shed light on whether the expanded benefits have increased labor force participation or other social benefits (Miller et al. 2015). However, although the research is still ongoing, these two pilot expansions provide an example of an update to the existing EITC policy to address the needs of low income childless workers, which can then inform federal policymakers.

\section{CONCLUSION}

Because of the demonstrated benefits of the EITC in reducing poverty, incentivizing employment, and improving social outcomes of the recipients, lawmakers should expand the benefit available to childless workers. While prioritizing tax benefits for workers with children is understandable due to resource constraints, closing the gap between workers with and without children is essential to further reduce the amount of workers taxed into poverty. In addition to the significant amount of research outlining the benefits of the EITC, the Paycheck Plus program and concurrent evaluation provide an example of a possible expansion method and encourage a data-driven approach for reform.

\section{REFERENCES}

Adireksombat, K. 2010. “The Effects of the 1993 Earned Income Tax Credit Expansion on the Labor Supply of Unmarried Women.” Public Finance Review 38: 11-40. Accessed December 3, 2016. doi:10.1177/1091142109358626.

Carasso, Adam, Harry J. Holzer, Elaine Maag, and C. Eugene Steuerle. 2008. “The Next Stage for Social Policy: Encouraging Work and Family Formation among LowIncome Men." Urban Institute and Brookings Institution Tax Policy Center, October 22. http://tpcprod.urban.org/UploadedPDF/411774_ encouragingwork.pdf

Crandall-Hollick, Margot L. 2015. “The Earned Income Tax Credit (EITC): An Economic Analysis." Congressional Research Service, June 2. https://files.taxfoundation.org/legacy/docs/2015-13069-1.pdf 
Edelman, Peter, Mark Greenberg, Steve Holt, Harry Holzer. 2009. "Expanding the EITC to Help More Low-Wage Workers." Georgetown Center on Poverty, Inequality, and Public Policy: 1-13. Accessed December 3, 2016.

http://www.urban.org/sites/default/files/alfresco/publication-pdfs/1001341Expanding-the-EITC-to-Help-More-Low-Wage-Workers.PDF

Edwards, Chris and Veronique de Rugy. 2015. "Earned Income Tax Credit: Small Benefit, Large Costs.” Downsizing Government, Cato Institute, October 1. Accessed January 22, 2017. https://www.downsizinggovernment.org/earnedincome-tax-credit\#_edn17

Eissa, Nada, and Hilary W. Hoynes. 2006. "Behavioral Responses to Taxes: Lessons from the EITC and Labor Supply." Tax Policy and the Economy 20: 73-110. Accessed December 3, 2016.

Executive Office of the President and U.S. Treasury Department. 2014. “The President's Proposal to Expand the Earned Income Tax Credit." March 2014. https://www. obamawhitehouse.gov/sites/default/files/docs/eitc_report_0.pdf.

Evans, William N. and Craig L. Garthwaite. 2014. "Giving Mom a Break: The Impact of Higher EITC Payments on Maternal Health.” American Economic Journal: Economic Policy 6 (2): 258-290. Accessed December 3, 2016. doi:http://dx.doi. org/10.1257/pol.6.2.258.

Goodman-Bacon, Andrew, and Leslie McGranahan. 2008. "How Do EITC Recipients Spend Their Refunds?” Economic Perspectives: Federal Reserve Bank of Chicago 32, no. 2: 17-32. Accessed December 3, 2016.

Hotz, V. Joseph, Charles H. Mullin, and John Karl Scholz. 2006. "Examining the Effect of the Earned Income Tax Credit on the Labor Market Participation of Families on Welfare." National Tax Journal LXI, 2: 189- 203. Accessed December 3, 2016.

IRS (Internal Revenue Service). 2008. “EITC Initiatives Report 2008.” Accessed December 3, 2016. https://www.irs.gov/pub/irs-utl/final_eitc_initiatives_ report_final_121708.pdf

2016. "EITC Information for the Press." Last modified December 9, 2016. https://www.eitc.irs.gov/EITC-Central/press/

Kneebone, Elizabeth and Jane R. Williams. 2014. "EITC Expansion Would Strengthen Credit for Childless Workers.” The Brookings Institution, March 18. https://www.brookings.edu/research/eitc-expansion-would-strengthen-creditfor-childless-workers/ 
LaLumia, Sara. 2013. “The EITC, Tax Refunds, and Unemployment Spells.” American Economic Journal: Economic Policy 5, no. 2: 188-221. Accessed December 3, 2016.

Linnenbrink, Mary, Michael Rupured, Teresa Mauldin, and Joan Koonce Moss. 2006. "The Earned Income Tax Credit: Experiences from and Implications of the Voluntary Income Tax Assistance Program in Georgia." Paper Presented at the Eastern Family Economics and Resource Management Association Conference, 2006.

Maag, Elaine. 2015. "Investing in Work by Reforming the Earned Income Tax Credit." Urban Institute and Brookings Institution Tax Policy Center, May 20. Accessed January 22, 2017. http://webarchive.urban.org/UploadedPDF/2000232investing-in-work-by-reforming-the-eitc.pdf

Marr, Chuck, Nathaniel Frentz, Sharon Parrott, Arloc Sherman, and Chye-Ching Huang. 2014. "Lone Group Taxed Into Poverty Should Receive a Larger EITC." Center on Budget and Policies Priorities, April 14. Accessed December 7, 2016. http://www.cbpp.org/research/lone-group-taxed-into-poverty-should-receivea-larger-eitc

Marr, Chuck and Chye-Ching Huang. 2015. "Strengthening the EITC for Childless Workers Would Promote Work and Reduce Poverty." Center on Budget and Policies Priorities, February, 20. Accessed December 3, 2016. http://www.cbpp.org/research/strengthening-the-eitc-for-childless-workerswould-promote-work-and-reduce-poverty

McCubbin, Janet. 2000. "EITC Noncompliance: The Determinants of the Misreporting of Children." National Tax Journal 53 (4): 1135-1164. Accessed December 7, 2016.

Meyer, Bruce D. 2010. “The Effects of the Earned Income Tax Credit and Recent Reforms." Tax Policy and the Economy 24, no. 1: 153-80. Accessed December 7, 2016. doi:10.1086/649831.

Miller, Cynthia, Caroline Schultz, and Alexandra Bernardi. 2015. “Testing an Expanded Earned Income Tax Credit for Single Adults: Year 1 of Paycheck Plus." MDRC Policy Brief. Accessed December 7, 2016. http://www.nyc.gov/html/ceo/ downloads/pdf/policybriefs/paycheckplus_policy_brief_2015.pdf

Paletta, Damian. 2014. “Obama Calls for Expanding EITC for Childless Workers." The Wall Street Journal, January 28. Accessed December 7, 2016. http://blogs.wsj. com/washwire/2014/01/28/obama-calls-for-expanding-eitc-for-childlessworkers/ 
Payment Accuracy. 2016. "Earned Income Tax Credit - Payment Accuracy." Last modified September, 2016. https://paymentaccuracy.gov/program/earnedincome-tax-credit/.

Rubio, Marco. 2014. "Reclaiming The Land Of Opportunity: Conservative Reforms For Combatting Poverty." Remarks as Prepared For Delivery U.S. Capitol Lyndon B. Johnson Room Washington, D.C, January 8. Accessed December 7, 2016. http://www.rubio.senate.gov/public/index.cfm/2014/1/rubio-deliversaddress-on-50th-anniversary-of-the-war-on-poverty

Ryan, Paul. 2014. "Expanding Opportunity in America." A Discussion Draft from the House Budget Committee, July 24. Accessed December 7, 2016. http://budget. house.gov/uploadedfiles/expanding_opportunity_in_america.pdf

Schuyler, Michael and William McBride. 2015. “The Economic Effects of the Rubio-Lee Tax Reform Plan.” Tax Foundation Fiscal Fact, No. 457, March 9. Accessed January 22, 2017. https://taxfoundation.org/economic-effects-rubio-lee-taxreform-plan/

Slemrod, Joel, and Jon M. Bakija. Taxing Ourselves: A Citizen's Guide to the Debate over Taxes. Cambridge, MA: MIT Press, 2008.

Trampe, Paul. 2007. “The EITC Disincentive: The Effects on Hours Worked from the Phase-out of the Earned Income Tax Credit." Econ Journal Watch 4, no. 3: 308320. Accessed December 7, 2016.

United States Census Bureau. 2017. "United States Census Bureau Data - Poverty Thresholds, 2016." Last modified January 31, 2017. http://www.census.gov/data/ tables/time-series/demo/income-poverty/historical-poverty-thresholds.html

Urban Institute and Brookings Institution Tax Policy Center. 2016. "Earned Income Tax Credit Parameters, 1975-2016.” Last modified January 5, 2016. http://www. taxpolicycenter.org/statistics/eitc-parameters

Wheaton, Laura, and Elaine Sorensen. "Extending the EITC to Noncustodial Parents: Potential Impacts and Design Considerations." Journal of Policy Analysis and Management 29, no. 4 (2010): 749-68. Accessed December 7, 2016. doi:10.1002/pam.20533. 
JENNIFER LEWIS is a second-year Master of Public Policy candidate at the Trachtenberg School, with a concentration in program evaluation and analysis. She graduated from Birmingham-Southern College in 2014 with a Bachelor of Arts in History and Political Science. While at Birmingham-Southern, she interned with several organizations, including a nonprofit in Washington, D.C. focused on ending homelessness. This experience developed her interest in social policy and her love of D.C. After graduation, she worked in Alabama at a political polling and strategy firm before transferring to their D.C. office, where she is currently employed.

\section{ACKNOWLEDGEMENTS}

The author would like to thank Dr. Diane Lim, whose enthusiasm for tax policy and engaging teaching methods inspired this project. She would also like to thank the Policy Perspectives team and Editor-in-Chief Joshua Garties for his thoughtful comments and feedback, as well as her faculty reviewer Professor David Brunori for his guidance and expertise. The author expresses her immense gratitude to Associate Editor Haley Dunn for her dedication, insight, and support throughout the publication process. Lastly, she would like to thank her family for their continual love and encouragement. 